DOI: https://doi.org/10.15407/preislamic2021.02.109

UDC 299.21

\title{
TEMPLE PERSONNEL AND RITUAL PRACTICE OF THE ESAGIL TEMPLE IN THE SECOND MILLENNIUM BC
}

\author{
I. Yu. Lapushanski \\ $\mathrm{PhD}$ Student \\ Belarusian State University \\ 6, Krasnoarmeyskaya Str., Minsk, 220030, Belarus \\ mixweidner@gmail.com
}

The composition of temple personnel and ritual practice of the main Babylonian temple Esagil (dedicated to the god Marduk) in the second millennium BC is insufficiently studied, a situation caused directly by the state of preservation of the relevant sources. The author examines parts of the Code of Hammurapi, administrative texts, and New Year festival fragment VAT 16435 to partially reconstruct the composition of the temple personnel (nadìtu-priestesses, pašǐšsu-priests, and šangû-priests). The following conclusions are drawn based on the data of prayers, incantations, and Poem of the righteous sufferer (Ludlul bèl nèmeqi) concerning ritual practice in Esagil: 1. The

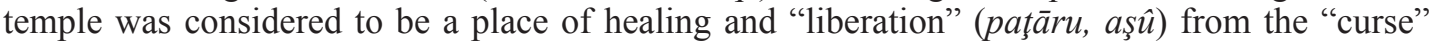
(mamitu) or illness, restoration of a person's social status; 2. Semi-divine creatures, residents of Esagil, were mediators of these processes; 3 . Healing of a person was accompanied by sacrifices in the temple, made for Marduk, his divine wife Zarpanitu, and protective gods of Esagil.

Keywords: Esagil, Babylonian religion, priesthood, ritual

\section{I. Ю. Лапушанскі \\ ХРАМАВЫ ПЕРСАНАЛ І РЫТУАЛЬНАЯ ПРАКТЫКА ЭСАГІЛЫ ў ІІ ТЫС. ДА Н. Э.}

Паколькі тэкстаў з храма Эсагіла ці яго ваколіцаў, якія б адносіліся да старававілонскага (каля 2001-1595 гг. да н. э.) ці сярэдневавілонскага (каля 1595 г. - канец II тыс. да н. э.) перыядаў, практычна не захавалася, досыць цяжка вызначыць становішча храмавага персаналу Эсагілы ды характар рытуальнай практыкі ў храме. 3 храмавага персаналу нам вядомыя nadītum і pašǐšsum Мардука ў старававілонскіх тэкстах i šangû Мардука ў тэкстах другой паловы II тыс. да н. э.

Спярша разгледзім старававілонскія дакументы. Цікавасць уяўяляе § 182 юрыдычнай часткі “Законаў Хамурапі”, у якім гаворка вядзецца аб спадчыне жрыцы nadītum бога Мардука з Вавілона. У §§ 179-182 абмяркоўваюцца ўмовы атрымання спадчыны жрыцамі пэўных катэгорый (nadītum, šerīktum і г. д.), ускосна i іх сацыяльны стан. Гэтыя катэгорыі былі так ці інакш звязаныя з храмам галоўнага бога горада, як можна меркаваць па дакументах са старававілонскага Сіпара [Harris 1963, 156157]. У той жа час яны мелі пэўную аўтаномію, так званыя “кляштары” (bït gagîm), дзе жылі жрыцы, функцыянавалі як асобная ад храму ўстанова [Harris 1963, 135]. Аднак жа адміністрацыя bìt gagîm была звязаная з храмам [Harris 1963, 131-142]. Акрамя таго, жрацы- šang $\hat{u}$, якія ачольвалі адміністрацыйную структуру храма Шамаша, заўжды ўзгадваюцца першымі ў спісе сведкаў у кантрактах, звязаных з дзейнасцю nadītum [Harris 1961, 118; Harris 1963, 157].

Параграф 182 [Bergman 1953, 25] “Законаў Хамурапі” спецыяльна вылучае з сукупнасці жрыц катэгорыю nadīt Marduk ša Bābilim "nadītum Мардука з Вавілона": "калі бацька сваёй дачцы, жрыцы-nadītum Мардука з Вавілона, не надаў пасагу і не запісаў 
яго ў дагаворы, пасля смерці бацькі з маёмасці дома бацькі яна падзеліць траціну (маёмасці), яе спадчыну, і не будзе несці павіннасці-ilkum. Жрыца- naditum Мардука з Вавілона перад смерцю можа распарадзіцца сваёй маёмасцю так, як ёй будзе заўгодна"1. У параграфе агаворваецца, што ў выпадку, калі бацька жрыцы не дасць ёй пасагу, яна падзеліць спадчыну “дома яе бацькі” разам з братамі (хоць і атрымае меншую долю), да даго ж усім, што застанецца пасля яе, яна можа распараджацца самастойна.

Адрозненне nadītum Мардука ад іншых nadītum заключаецца ў апошнім пункце: маёмасць іншых жрыц пасля іх смерці пераходзіць да іх братоў. Акрамя таго, nadītum Мардука не мусілі несці павіннасці- ilkum. Такім чынам, жрыцы Мардука знаходзіліся ў прывілеяваным стане ў адносінах да іншых жрыц. Верагодна, гэта было звязана са сталічным статусам Вавілона і асаблівымі адносінамі цароў Першай вавілонскай дынастыі да культу Мардука.

Тое, што гэтыя жрыцы былі звязаныя з Эсагілай, падцвярджае ўказанне "Мардук з Вавілона", пакліканае, хутчэй за ўсё, адрозніць іх жрыц храмаў Мардука ў іншых гарадах (напрыклад, храма Эзіда) [Frayne 1990, E4.3.6.17].

Яшчэ адна крыніца, якая пралівае святло на гісторыю Эсагілы ў старававілонскі перыяд, датычыць выдачы масла жрацу-pašĭšum бога Мардука. Прыводзім яе транслітарацыю і пераклад [Delitzsch 1909, № 194]:

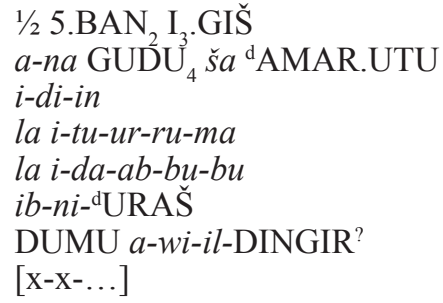

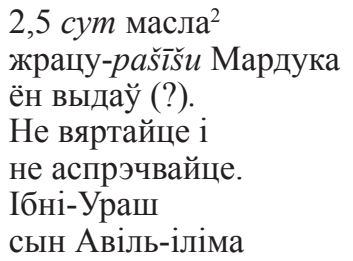

Назва катэгорыі жрацоў- раšǐš (часта яна запісваецца шумераграмай GUDU [Black 2000, 269]) звычайна перакладаецца як “жрэц-умашчальнік” [Renger 1967, 57]. Яны займаліся ўмашчэннем статуй багоў, а таксама ахвярамі і лібацыямі. Шумерская літаратура звязвае іх гэтаксама 3 рытуаламі ачышчэння (šu-luh). Выраз pašišum ša Marduk верагодна адносіцца да культавага персаналу Эсагілы, бо нам невядомыя культавыя цэнтры бога ў раёне Дзільбата, адкуль паходзіць дакумент.

Адзіным добра захаваным і зразумелым рытуальным тэкстам II тыс. да н. э., датычным культа Мардука, з’яўляецца фрагмент навагодняга рытуалу VAT 16435 [Köcher 1952]. Гэты тэкст паходзіць з асірыйскай сталіцы горада Ашура, але, верагодна, апісвае навагодні рытуал у Вавілоне. У рытулае фігуруюць цар і жрэц-šangû, што адрознівае яго ад апісання вавілонскага навагодняга рытуалу I тыс., дзе ў якасці вярхоўнага жраца Эсагілы выступае жрэц-ร̌šsgallu. Падчас рытуалу цар і жрэц здзяйсняюць багатыя ахвярапрынашэнні перад Мардукам (крывавыя ахвяры авечак, высыпанні кедра, мукі, ядлоўца на ахвярных авечак, лібацыі вадой, півам і віном). Падобна, што тэкст апісвае выхад Мардука з Эсагілы для здзяйснення падарожжа ў іншы храм; у рытуале I тыс. Мардук накіроўваецца на сваёй лодцы да bìt akīti “Дому навагодняга рытуалу”, аднак y VAT 16435 месца прызначэння не называецца. Указваецца толькі, што Мардука, Царпаніту і Набу падымаюць на рытуальныя чоўны. Цікава, што човен Мардука таксама згадваецца ў рытуальным тэксце старававілонскага перыяду [Wasserman 2006], а аднаўленне яго чоўну згадваецца ў “Прароцтве Мардука” [Neujahr 2012, 31].

\footnotetext{
${ }^{1}$ šumma abum ana mārtī̌šu nadīt Marduk ša Bābilim šeriktam lā išrukšim kunukkam lā išturšim warka abum ana šîmtim ittalku ina makkūr bìt abim šalušti aplütiša itti ahhiša izâzma ilkam ul illak nadīt Marduk warkassa èma elīša ţābu inaddin.

${ }^{2}$ Каля 25 літраў.
} 
Храмавы персанал і рытуальная практыка Эсагілы ў II тыс. да н. э.

Бог Мардук $з$ часу цара Хамурапі стаў успрымацца як бог-экзарцыст. Гэты аспект бажаства быў, верагодна, звязаны з тым, што Мардук з'яўляўся сынам бога Эа, які быў галоўным богам магіі ў вавілонскім пантэоне. У многіх заклёнах, напрыклад, у серы $\breve{S u r p u, ~ а п і с в а е ц ц а ~ д ы я л о г ~ п а м і ж ~ М а р д у к а м ~ і ~ Э а, ~ п а д ч а с ~ я к о г а ~ м а л о д ш ы ~}$ бог просіць парады ў бацькі з нагоды лячэння хворага. Эа, як правіла, кажа, што Мардук ведае ўсё, што вядома самому Эа, а затым апісвае працэдуру лячэння і неабходныя замовы [Reiner 1958, 1].

Дзякуючы гэтай якасці бога, яго храм апісваўся ў тэкстах як месца вылячэння. Гэтая тэма найбольш падрабязна раскрываецца ў малітвах, заклёнах і “літаратуры мудрасці”, прысвечаных богу Мардуку - гэта стара- або сярэдневавілонская малітва VS 2497 [Oshima 2011, 198-201], радкі 151-154 і 157 другой табліцы серыі загавораў "Šитрu” [Reiner 1958, 17], а таксама заключная частка паэмы пра нявіннага пакутніка (Ludlul bēl nēmeqi) [Lambert 1963, 21-62].

Малітва VS 2497 звернута да Мардука і багоў Эсагілы. У ёй чалавек, які імкнецца знішчыць “праклён (mamītu)” і ўсталяваць “вызваленне (aşû)”, адпраўляецца для гэтай мэты самім Мардукам у Вавілон і Эсагілу (радкі 4-8). Акрамя таго, у малітве, магчыма, упершыню згаданы боскія служкі Эсагілы Надзін-мэ-кацім (Nädin mê qatim, "Хто дае ваду рук”) і Мукіль-мэ-балацім (Mukīl mê balāţim, "Хто трымае ваду жыцьця") (радкі 10-11), а таксама паўбоскія фантастычныя жывёлы, выявы якіх, як вядома, упрыгожвалі дзверы цэлы Мардука ў Эсагіле. Іх функцыя, як вынікае 3 тэксту малітвы, - служыць медыятарамі паміж чалавекам і Мардукам, яны павінны былі перадаваць богу просьбы людзей (радкі 10-15).

У серыі загавораў “Šиrрu” Эсагіла згадваецца разам з Вавілонам, Мардукам і Царпаніту як месца, якое здольнае “вызваліць (paţāru)" чалавека ад яго хваробы (радкі 153-154: Esagil и Bābili lipţur, šubat ilāni rabûti). У гэтай частцы серыі жрэцзаклінальнік заклікае розных багоў, храмы і гарады вызваліць чалавека, пры гэтым магчыма, што іх парадак мае іерархічную прыроду (першымі згаданыя кіраўнік пантэона - бог Ану і багіня Анту, затым бог Энліль і багіня Нінліль, затым бог Эа і багіня Дамкіна, затым бог Мардук і багіня Царпаніту).

Нарэшце, герой паэмы пра нявіннага пакутніка ў канцы твору адпраўляецца ў Эсагілу, дзе аднаўляецца яго статус. Ён праходзіць рытуальную працэсію праз брамы храма, назвы якіх напрамую звязаны 3 пэўнай якасцю, якая вяртаецца да раней пазбаўленага яе чалавека (напрыклад, радок IV 82: “у браме жыцця я атрымаў жыццё (ina bāb balāţi balāţa ammahir)”) (радкі IV 77-90). Нарэшце герой сустракаецца з багамі Мардукам і Царпаніту і здзяйсняе малітвы і багатыя ахвярапрынашэнні (згаданыя ахвяры быкоў, авечак, лібацыі піва і віна) (радкі IV 89-95). Пасля гэтага герой здзяйсняе ахвяры духам-абаронцам (шэду і ламасу) Эсагілы, а таксама некаторым аб'ектам унутры храма (згаданыя ахвяры алеем, тварагом і адборным збожжам) (радкі IV 96-100).

Такім чынам, на падставе тэкстаў малітваў, загавораў і паэмы пра нявіннага пакутніка мы можам зрабіць наступныя высновы:

1) Храм Эсагіла разглядаўся як месца, у якім адбываецца вылячэнне чалавека, яго “вызваленне" (pațāru, aşû) ад “праклёну” (mamītu) або хваробы, аднаўленне яго статусу;

2) Медыятарамі ў гэтым працэсе служылі паўбоскія стварэнні, што жылі ў храме;

3) Вылячэнне чалавека суправаджалася ахвярапрынашэннямі ў храме, якія рабіліся як для Мардука і Царпаніту, так і для духаў-абаронцаў Эсагілы.

\section{REFERENCES}

Bergman E. (1953), Codex Hammurabi. Textus primigenius, Pontificium institutum biblicum, Roma. 
Black J., George A. and Postgate N. (2000), Concise Dictionary of Akkadian, Harassowitz Verlag, Wiesbaden.

Delitzch F. (1909), Vordeasiatische Shriftdenkmäler der königlichen Museen zu Berlin, Helf VII, J. C. Hinrichs'sche Buchhandlung, Leipzig.

Frayne D. (1990), Royal Inscriptions of Mesopotamia, Early Periods, Vol. 4: Old Babylonian Period (2003-1595 BC), University of Toronto Press, Toronto.

Harris R. (1961), "On the Process of Secularization under Hammurabi”, Journal of Cuneiform Studies, No. 4, pp. 117-20.

Harris R. (1963), "The Organization and Administration of the Cloister in Ancient Babylonia", Journal of the Economic and Social History of the Orient, Vol. 6, No. 2, pp. 121-57.

Köcher F. (1952), "Ein mittelassyrisches Ritualfragment zum Neujahrsfest", Zeitschrift für Assyriologie und Vorderasiatische Archäologie, Bd. 50, pp. 192-202.

Lambert W. G. (1963), Babylonian Wisdom Literature, Oxford University Press, Oxford.

Neujahr M. (2012), Predicting the Past in the Ancient Near East: Mantic Historiography in Ancient Mesopotamia, Judah, and the Mediterranean World, Brown University, Providence.

Oshima T. (2011), Babylonian Prayers to Marduk, Mohr Siebeck, Tübingen.

Reiner E. (1958), Šurpu: A Collection of Sumerian and Akkadian Incantations, im Selbstverlage des Herausgebers, Graz.

Renger J. (1967) "Untersuchungen zum Priestertum der altbabylonischen Zeit. 1. Teil”, Zeitschrift für Assyriologie und Vorderasiatische Archäologie, Bd. 58, No. 1, pp. 110-88.

Wasserman N. (2006), "BM 29638: A New Ritual to Marduk from the Old Babylonian Period", Zeitschrift für Assyriologie und Vorderasiatische Archäologie, Bd. 96, pp. 200-11.

\section{I. Ю. Лапушанскі}

ХРАМАВЫ ПЕРСАНАЛ І РЫТУАЛЬНАЯ ПРАКТЫКА ЭСАГІЛЫ Ў ІІ ТЫС. ДА Н. Э.

Склад храмавага персаналу і рытуальная практыка галоўнага вавілонскага храма Эсагіла, прысвечанага богу Мардука, у II тыс. да н. э. вывучаны слаба, што звязана ў першую чаргу з характарам захаваных крыніц. Аўтар разглядае дадзеныя Законаў Хамурапі, адміністрацыйных тэкстаў, фрагмента навагодняга рытуалу VAT 16435 для частковай рэканструк-

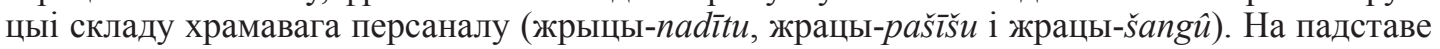
тэкстаў малітваў, загавораў і "Паэмы пра нявіннага пакутніка" робяцца наступныя высновы аб характары рытуальнай практыкі ў Эсагіле: 1) Храм Эсагіла разглядаўся як месца, у якім адбываецца вылячэнне чалавека, яго "вызваленне" (paţāru, aşû) ад “праклёну" (mamītu) або хваробы, аднаўленне яго статусу; 2) Медыятарамі ў гэтым працэсе служылі паўбоскія стварэнні, што жылі ў храме; 3) Вылячэнне чалавека суправаджалася ахвярапрынашэннямі ў храме, якія рабіліся як для Мардука і Царпаніту, так і для духаў-абаронцаў Эсагілы.

Ключавыя словы: вавілонская рэлігія, жрэцтва, рытуал

\section{I. Ю. Лопушанський}

ХРАМОВИЙ ПЕРСОНАЛ І РИТУАЛЬНА ПРАКТИКА ЕСАГІЛИ В ІІ ТИС. ДО Н. Е.

Склад храмового персоналу і ритуальна практика головного вавилонського храму Есагіл, присвяченого богу Мардуку, в II тис. до н. е. вивчені слабо, що пов'язано в першу чергу 3 характером джерел, що збереглися. Автор розглядає дані Законів Хаммурапі, адміністративних текстів, фрагмента новорічного ритуалу VAT 16435 для часткової реконструкції складу храмового персоналу (жриці надіту, жерці пашішу і шанг). На підставі текстів молитов, заклинань і "Поеми про невинних страждальців" робляться наступні висновки про характер ритуальної практики в Есагілі: 1) храм Есагіл розглядався як місце, в якому відбувається зцілення людини, його “звільнення” (paţāru, aşû) від “прокляття” (mamītu) або хвороби, відновлення його статусу; 2) медіаторами в цьому процесі служили напівбожествені створіння, які жили в храмі; 3) зцілення людини супроводжувалося жертвопринесеннями в храмі, що здійснювалися як для Мардука та Царпаніту, так і для духів-захисників Есагіли.

Ключові слова: Есагіл, вавилонська релігія, жрецтво, ритуал 